Boedov, A.A. (2020). Tradition as a factor of self-organization of society. Past and present in the philosophy of social development. Collection of Scientific Articles. European Scientific e-Journal, 2 (2), 17-24. Hlučín-Bobrovníky: "Anisiia Tomanek" OSVČ.

Боедов, А.А. (2020). Традиция как фактор самоорганизации общества. Past and present in the philosophy of social development. Collection of Scientific Articles. European Scientific e-Journal, 2 (2), 17-24. Hlučín-Bobrovníky: “Anisiia Tomanek" OSVČ. (на англ.)

DOI: $10.47451 /$ phi2020-08-001

The paper will be published in Crossref, ICI Copernicus, Academic Resource Index ResearchBib, J-Gate, ISI International Scientific Indexing, Zenodo, OpenAIRE, BASE, LORY, LUASA, ADL, eLibrary, and WebArchive databases.

Andrey A. Boedov, Researcher in Philosophical Sciences, A.S. Pushkin Leningrad State University. St. Petersburg, Russia.

\title{
Tradition as a factor of self-organization of society
}

Abstract: Considering the process of self-organization of such a complex evolving system as human society, it seems necessary to determine the role and significance of such a phenomenon as tradition in it. Interest in tradition is actively growing in society, which can be explained to a certain extent by new psycho-historical challenges, the precarious state of the world, the increase in entropy, the growth of hostility and global chaos. The article deals with the phenomenon of tradition, which acts as a factor of self-organization of society. The analysis of tradition and tradition in the context of cultural-historical and cultural-psychological approaches is carried out. The role and significance of tradition in the system of functioning and development of social organisms of various levels are noted. The author concludes that traditions and the process of tradition are a kind of protection against the fragmentation of the world, limiting its fragmentation, and this mission is particularly in need of impulses to unite with reality, society in general and a small social group in particular. As a result, "tradition" becomes a psychological practice of self-organization of society, an antientropic factor.

Keywords: tradition, traditional values, self-organization of society, the making of symbols out, neotraditionalism.

Андрей А. Боедов, исследователь в области философии, Аенинградский государственный университет им. А.С. Пушкина. Санкт-Петербург, Россия.

\section{Традиция как фактор самоорганизации общества}

Аннотачия: Рассматривая процесс самоорганизации такой сложной развивающейся системы как человеческое общество, представляется необходимым определить роль и значение в ней такого явления, как традиция. В обществе активно растёт интерес к традициям, что в определённой степени объясняется новыми психо-историческими вызовами, шатким состоянием мира, ростом энтропии, ростом враждебности и глобальным хаосом. В статье рассматривается феномен традиции, выступающей как фактор самоорганизации общества. Проведён анализ традиции и традиции в контексте культурно-исторического и культурно-психологического подходов. Отмечаются роль и значение традиции в системе функционирования и развития социальных организмов разного уровня. Автор приходит к выводу, что традиции и процесс традиции яв яются своего рода защитой от фрагментации мира, ограничивая его фрагментацию, и эта миссия особенно нужАается в импульсах Аля объединения с реальностью, обществом в целом и 
небольшой социальной группой в частности. В результате «традиция» становится психологической практикой самоорганизации общества, антиэнтропийным фактором.

Ключевые слова: традиция, традиционные ценности, самоорганизация общества, создание символов, неотрадиционализм.

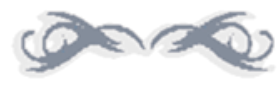

\section{Introduction}

Considering the process of self-organization of such a complex evolving system as human society, it seems necessary to determine the role and significance of such a phenomenon as tradition in it. Interest in tradition is actively growing in society, which can be explained to a certain extent by new psycho-historical challenges, the precarious state of the world, the increase in entropy, the growth of hostility and global chaos. In the sequence of new acute challenges and events, issues related to the traditional way of life and historical destinies of the people, including the development of civil consciousness in society, are being sharpened and updated. Civil society is considered to be one of the main catalysts for the development of mechanisms for selforganization of society. At the same time, tradition, as well as innovation, are the driving force of the development of society and civilization as a whole.

It is possible to consider the concept of "tradition" in both the narrow and broad sense of the word. The modern scientific discourse is dominated by a narrow understanding of the concept as a socio-cultural inheritance, an ethnic heritage based on a well-known definition, "Tradition is a set of ideas, customs, habits and skills of practical activity passed from generation to generation, acting as one of the regulators of public relations" (Averyanov, 2000). This definition is based on a cultural-historical approach, in which tradition is perceived as a conservative structure that is passed from generation to generation. In this context, the tradition is presented as something past, archaic, created by past generations and preserving the memory of them. The phenomenon of tradition in the historical, cultural and historical aspect has been thoroughly studied.

\section{The results of the study}

Given the current context and the emergence of a mass of new phenomena that occur everywhere, it is necessary to understand the phenomenon of tradition in a broad sense - as a special sphere, a model of behavior inherent in the human community, in the form of systematic modeling actions, types of communication that create, consolidate and affirm well-being and stability, balance and stability as its value. In this context, tradition assumes the role of a mechanism for self-preservation and self-organization of society and its groups. Modern social practice demonstrates a kind of "revolution of tradition", where, in connection with the new orientation, the shift of emphasis in the understanding and interpretation of tradition as a phenomenon of cultural and psychological reality was actualized. In the classical sense, priority is given to the concept of inheritance based on the connection of generations. "Tradition is a positive succession, that is, a certain order of inheritance. The meaning of the tradition is to preserve the inheritance, to ensure that the inheritance does not lose its stable positive properties" (Averyanov, 2000). In this sense, traditions can include any beliefs, social practices, 
institutions, and artifacts passed down from generation to generation. Usually, the concept of tradition refers to certain elements of culture that are considered the basis of the common heritage of a social group. At the same time, the content of tradition is not something absolutely static, dead, devoid of natural development. Tradition is often considered a source of legitimacy and social stability. M.V. Zakharchenko in the article of Cultural and Historical Tradition states, "the fundamental quality of human existence is the ability to create and inherit cultural works. Tradition in a broad sense, as an inheritance of culture, thus acts as a universal characteristic of the human way of being." (Zakharchenko, 2013) In this regard, it is advisable to consider tradition as a natural form of creative self-regulation and self-organization of human communities. The phenomenon of tradition is not so much related to social conservatism as it is an area of psychohistorical self-organization of cultural collectives, the value-emotional basis of social well-being and psychological correction. The social embodiment of the traditional scenario implies a joint experience of psychological unity, a desire for a common goal, a common experience of the value of what was lived in the past and what is lived in the present. The formation of a special sphere associated with consciousness, communication and action, the creation and actualization of the values of a positive Association of a given society. In this aspect, tradition is considered not so much in a historical way, but in a psychological way, as a form of self-organization of many individuals in a common creative project.

In this case, tradition is a kind of mechanism and Declaration of unity that affects the formation of a social group as a whole, it is a tool for merging a personal set into a single community, into a collective, and not into a crowd of individuals. In a broad sense, tradition can be considered as a special type of communication and behavior associated with the genetic program of identification inherent in human nature. The semantic code of the tradition and its psycho-historical scenario are determined by these tasks of self-organization and creativity that exist before it. The tradition itself turns out to be an artifact created in the process of social communication. At the same time, tradition removes the contradiction that exists between collectivism and individualism, being the only way to combine the individual activity of an independent person and the collective self-organization of many individuals within a common project. It is obvious that both individualism and collectivism in a primitive form cannot arrange a full-fledged personality, so a living tradition is the only way to ensure a full-fledged human being. In the absence of tradition, there may be either a primitive form of collectivism, a human herd', or perhaps a total decomposition of society into separate units, which, however, due to the personal weakness of these units, inevitably returns to herd conformism (Kara-Murza, 2004).

Reasoning about the phenomenon of tradition in the logic of cultural and psychological consideration of the elements of reality, we come to a number of consistent conclusions. It should be noted that as a historical phenomenon, tradition is accompanied by the process of tradition-the creation of new concepts and phenomena that fix the functions of a special ritualrelated action and communication aimed at maintaining the predictability and stability of everyday life, the harmonious stability of the social structure. Tradition, closely intertwined with the concepts of "custom", "rite", "habit", collectively characterize the socio-cultural aspect of society. Accordingly, the everyday culture of any people is based on a traditional combination of customs and rituals. At the same time, custom is a historically determined, present in the positive law order of society; shared by all, the usual and decent principle of actions and actions, 
dominating in a particular society or social group, with varying degrees of rigor observed by both individuals and social groups (Philosophical Encyclopedia, 2006). Custom is also understood as "a spontaneous pattern of behavior that has a normative meaning for members of society" (Modern Dictionary of Social Sciences, 2007). A rite is a combination of "individual or collective symbolic actions of believers that objectify their religious beliefs and are aimed at establishing otherworldly relations between a person and supernatural objects" (Modern Dictionary of Social Sciences, 2007). Traditions, customs, and habits are repetitive, recorded actions and materialized situations where a unique creative work with historical everyday life takes place-capturing the moment and transforming it as a sign. At the same time, it is necessary to distinguish norms of behaviour, a template action, a functional decision that forms a habit, from a rite as an action that is valuedriven, and, accordingly, traditions. In the sequence of these concepts, the level of sacralization increases, and the semioticization of objective reality and behavioral standards increases. Tradition plays a unique role in this system of symbolic design of everyday life.

Thus, tradition is a unique value-semantic, duplicative action, a communicative circle with a characteristic sacral-symbolic scenario, an ethical, Gnostic and aesthetic field, a system of values, a set of roles and rituals, a certain tool for expanding the human space in terms of its capabilities, rights, feelings, and values.

The elements of the traditional structure of the "communication-action" attitude:

- $\quad$ symbolic, symbolic, ritually-sacralized;

- implementation of the appropriate ritual roles associated with the moments of performing the ritual action;

- increasing the space of personal opportunities, granting the right and opportunity to increase the volume of consumption;

- expanding social horizons, correcting social status, including or removing taboos;

- formalized manifestations of ritual benevolence that unite participants in a traditional act;

- a traditional rule common to all ethnic groups associated with ritual generosity - the exchange of signs and gifts, the display of generosity and openness, spiritual breadth, wit and care.

One of the components of the tradition is the reinterpretation of reality, its modification and endowment with a higher meaning, the growth of vital acts and facts to the meaning of an existential symbol.

Tradition is inextricably linked with the system of communications, synchronous-diachronic dialogues that form the semantic space of culture and the psychological space of society. Tradition combines diachronic aspects of the formation of characteristic values of an ethnic group, society, state, and civilization with a synchronous dialogue of living activity, the process of creating meanings, and the endowment of the spiritual content of the carnal existence of every individual. The complementary system of dialogues manifests itself as a symbol of the presence of purpose and meaning, value and organization in life. The nature of tradition, which is essentially conventional, is associated with the high intensity of the communication processes involved in it. Tradition defines the degree of social cohesion due to the ways of unity through interaction systems and types of communication. This implies a unity that is not related to a 
common work or situational task, but is related to the type of communication. In a certain sense, tradition is a type of communication that includes a multi-level spectrum of communication.

A characteristic feature of any community is the desire to maintain communication sufficient to maintain the need for stability and repeatability, which includes iconic elements, symbolization of values associated with this community. The combination of a communicative and cybernetic approach allows us to consider tradition in a broad, universal sense. Traditions are one of the ways of self-organization of the life process, self-regulation of living systems, the activity of constantly reproducing and sacralizing the value of life, generating and maintaining stable, rhythmically reproducible and full of psychological content symbolic acts of communication. In a certain sense, traditions are a process of semioticization that forms a symbolic reading of the reality surrounding everyday life, which thereby acquires an additional assessment, meaningfulness and a special status of value that has a timeless meaning.

Assessing the mutual relations of tradition and innovation, it should be noted that innovation can be meaningless, lifeless, and the tradition is filled with active creative activity for self-reflection and self-development, continuous work on the development and transformation of the community. Tradition (creation of traditions) accompanies the emergence and approval of new communities and public projects. So, the historical and cultural approach to tradition, which considers it as a connection of times, is supplemented and gets a new development through the use of a cultural and psychological approach, the psychology of culture, as a way of human communication, the formation of a common standard of behavior.

The formation and evolution of social systems is characterized by the existence of special types of communication and behavior inherent in them - patterns of stability. In the process of functioning and evolution, a society that creates and distributes social roles and functions creates and preserves its own special, local types of communication, corresponding signs, symbols, rituals - traditions designed to culturally and psychologically consolidate its image, its own value and the unity of its members.

The tradition is characterized by a special intensity of communication (Bell, 1990), represented by various types and forms, the acuteness of experience and joint perception of participants. Tradition reproduces patterns, not stereotypes of behaviour, overcoming the ephemerality of life, connecting the temporary with the eternal. The tradition has the idea of "always": "we always do this", which testifies to its inherent principle of immutability, continuity, stability of values. There are many problems and conflicts related to this, which arise in connection with public contradictions about the attitude to certain traditions. Thus, the replacement of some holidays with others is connected not only with amendments to the calendar, but with a certain ideological turn of society, its turn to other values.

In the context of modern events, the fundamental, rather than facade-decorative, meaning of traditions, which are codes of super personal values of society and man, becomes clear. The role of tradition as a real creative process that creates a worldview and forms life attitudes, as tools for programming life scenarios, is clarified.

Social practice shows the evolution patterns of stability from the tradition of local historicalcultural, then religious and philosophical, and on to the universal world spiritual and psychological traditions that underlie historical, cultural, religious-philosophical, political and economic traditions, uniting the human society and being enduring super value. 
So, traditions can be attributed to open systems filled with life creativity, while in the tradition there is a commemoration of reality, the identification of values, the sacralization and mythologization of the life of society and man. The place, time, and mode of action are filled with spiritual content in the tradition.

The most important task for contemporaries is the need to understand tradition not as a facade decoration for everyday life, but as a fundamental essential phenomenon that consolidates society, which is an important factor of social consciousness and self-organization.

It should note that modern society is actively growing interest in ancient and archaic history, which can be explained by the desire to create a multidimensional perception of the world in the fullness of historical memory, meaningful in the context of modernity. Elements of the historical past are combined with the desire to modernize and update the world. There is a process and an ideological direction that can be "designated as new traditionalism and traditionalismneotraditionalism" (Lamazhaa, 2010). In modern reality, many different models of tradition are connected - historical and military, educational and scientific, national and spiritual and moral, religious and ethical, family, industrial, and communicative. At the same time, completely new patterns of stability and mechanisms for the semioticization of everyday life as an ongoing process of life creativity exist, are formed and fixed.

As a framework for the stability and self-identification of society, tradition becomes an individual and social value that makes up a significant part of the worldview of a person and his family, the circle of communication, and the spiritual and psychological space. On an international scale, tradition is the most important indicator of the personal image of the people and the country.

\section{Conclusion}

In the modern era of information technology and active promotion of the network space, the relevance of traditions and the process of tradition has received new confirmation. The institution of tradition is not only not canceled, but it finds all new functions and opportunities. Researcher A.V. Kostina, speaking about the significance of the tradition factor in the information society, as well as in the future knowledge society, notes, "at present, a kind of reactivation of the potential of traditionalism is evidenced by numerous facts related to the functioning of the network space as a kind of marker of the network information society. These are numerous network communities, the formation of a kind of art based on traditional forms, called "network folklore", and finally, these are fundamental forms of sociality, similar to traditional ones. Network communities are created because, going to them, a person gets the ability to resist the universality of the global world, he finds there "their" interests, views and is included in this community, seeing in this the possibility of their own realization - creative and spiritual (...). These behavioural structures, which resemble those that defined human behavior in traditional collectives, help to bridge the "three lines of gap" between people who receive different quality of education, between generations that represent tradition and innovation, and between those who were born before the computer revolution and after it. It is possible to overcome these types of fragmentation by uniting into global "tribes" of people based on the unity of life positions." (Kostina, 2010) Thus, traditions and the process of tradition are a kind of protection against the fragmentation of the world, limiting its fragmentation, and this mission is 
particularly in need of impulses to unite with reality, society in general and a small social group in particular. As a result, "tradition" becomes a psychological practice of self-organization of society, an antientropic factor.

The birth of new traditions is one of the conditions for the normal development of social organisms of various levels as a self-support of their unity, communicative stability, cultural and psychological unity, and a pronounced system of values.

\section{References:}

Averyanov, V.V. (2000). Tradition as continuity and service. Moscow: Man. (in Russian)

Bell, D. (1990). Cultural contradictions of capitalism. Ethical Thought: scientific publicist. Moscow: Politizdat. (in Russian)

Kara-Murza, S.G. (2004). Manipulation of consciousness. Moscow: Algorithm. (in Russian)

Kostina, A.V. (2010). Global information society: contradictions of cultural development. Cultural Magazine, 2. (in Russian)

Lamazhaa, Ch.K. (2010). Knowledge. Understanding. Skill. Moscow: Moscow State University for the Humanities. (in Russian)

Modern Dictionary of Social Sciences (2007). Moscow: Eksmo. (in Russian)

Philosophical Encyclopedia (2006). Moscow: Infra-M, 2006. (in Russian)

Zakharchenko, M.V. (2013, October 7). Cultural and historical tradition. Retrieved May 12, 2020, from http://www.portal-slovo.ru/pedagogy/37922.php (in Russian) 